\title{
Cost-effective cellulase production using Parthenium hysterophorus biomass as an unconventional lignocellulosic substrate
}

\author{
Anita Saini $^{1}$ - Neeraj K. Aggarwal ${ }^{1} \cdot{\text { Anita } \text { Yadav }^{2}}^{2}$
}

Received: 4 August 2016/ Accepted: 7 January 2017/Published online: 8 April 2017

(c) The Author(s) 2017. This article is an open access publication

\begin{abstract}
The potential of untreated Parthenium hysterophorus weed biomass was evaluated as a substrate for cellulase production. The cellulose in the biomass was used as the main source of carbon. Solid-state fermentation was carried out using Trichoderma reesei, and optimization of cultural conditions was done for maximization of cellulase production. The results revealed that highest cellulase production was achieved on the 8th day of incubation, at $30{ }^{\circ} \mathrm{C}$, keeping solid-to-liquid ratio $1: 2$ when two discs of inoculum were used per gram of the substrate. The optimized inoculum age was $96 \mathrm{~h}$ for CMCase and $120 \mathrm{~h}$ for FPase. On studying the enhancing effect of different carbon and nitrogen sources, lactose and ammonium molybdate were found suitable, respectively. The optimized concentration of lactose for the highest CMCase and FPase activities was 1.5 and $1 \%$, respectively. Ammonium molybdate was best at $1 \%$ concentration for both CMCase and FPase. Maximum CMCase and FPase activities obtained were 20.49 and $2.42 \mathrm{U} / \mathrm{gds}$, respectively.
\end{abstract}

Keywords Cellulase - Cost effective - Lignocellulosic . Weed · Parthenium hysterophorus $\cdot$ Trichoderma reesei

Neeraj K. Aggarwal

neerajkuk26@rediffmail.com

1 Department of Microbiology, Kurukshetra University, Kurukshetra 136119, Haryana, India

2 Department of Biotechnology, Kurukshetra University, Kurukshetra, Haryana, India

\section{Introduction}

Cellulose is the most abundant biopolymer on earth (Klemm et al. 2005), which constitutes the primary component (35-50\%) of lignocelluloses (Limayem and Ricke 2012). It accounts for the significantly high amount of the carbon recycled in the global carbon cycle and presents a huge sink, which reserves tons of the carbon fixed each year (Brown 1979) in both terrestrial and aquatic habitats. Cellulose is the high molecular weight linear polymer of Dglucopyranose units linked together by $\beta$ - $(1 \rightarrow 4)$-glycosidic bonds (Brodeur et al. 2011). Hydrolysis of this polymer is mediated by a complex of enzymes together referred as cellulases (Shahzadi et al. 2014). Recently, cellulases have gained worldwide attention due to their applications in many industries, such as textile, pulp and paper, detergent, biofuel, biogas, animal feed, and food (Sukumaran et al. 2005). Owing to such a wide array of applications, cellulases constitute the major proportion of the world's annual demand of enzymes. They make around $20 \%$ of all enzymes produced in the world (Damaso et al. 2012).

Cellulases are produced naturally by a wide variety of organisms, including bacteria, fungi, actinomycetes, protozoa, and some insects, molluscs, and nematodes (Wilson 2011). Filamentous fungi are potent cellulose degraders capable of producing large amounts of extracellular cellulases. Most of the commercial cellulase production relies on fungal genera of Aspergillus, Penicillium, and Trichoderma (Kirk et al. 2001; Cherry and Fidantsef 2003; Ruegger and Tauk-tornisielo 2004). Among these microbes, $T$. reesei is one of the prime interests of researchers for various studies aiming at increasing the production rate of cellulases by this fungus at industrial 
levels (Damaso et al. 2012; Klein-Marcuschamer et al. 2012).

The production cost of cellulases is very high which in turn makes its application processes quite expensive. Therefore, presently, reduction of cellulase production cost is the major goal of enzyme industries (Sukumaran et al. 2005). One important alternative to this is the production of the enzyme using renewable, economically feasible and readily procurable sources of nutrients for the growth of cellulase producing microorganisms. Lignocellulosic biomass presents the cheapest source for the same (Verma et al. 2011) and is an attractive substrate due to its abundance as well as diversity (Isarankura-Na-Ayudhya et al. 2007; Balat and Balat 2009). However, lignocelluloses are utilized in a broad spectrum of applications. Therefore, dependence on conventional lignocellulosic sources, such as agro-industrial residues, forest residues, or municipal waste, is not advocated. Increased demands of these sources may ultimately raise the issues of land management and biodiversity conservation. The unconventional sources, such as weeds, growing naturally in various ecological niches, can be an alternative, because they can be commenced as low-cost substrates for cellulase production. Parthenium hysterophorus is one of the world's seven most devastating weeds (Patel 2011). Management of this weed has been difficult by the common physical, chemical, and biological methods or integrative approaches. The lignocellulosic matter locked in its cell walls can be exploited efficiently for cellulase production by various microbes. This will simultaneously provide an efficient method for controlling this weed by its utilization.

The production of enzymes is not only influenced by biochemical and genetic characteristics of microbial systems but also by the nutritional and physiological conditions used during growth, which can be optimized for the production of enzymes in sufficiently high quantities.

In the present study, Parthenium biomass has been used for the production of cellulases by $T$. reesei and conditions have been optimized for maximizing cellulase production by the fungus under solid-state fermentation (SSF) conditions. The biomass has been used in the raw form, without any chemical pretreatment. The pretreatment of lignocellulosics is an energy intensive and costly affair. Therefore, Parthenium lignocellulose was used in the untreated form for the production of cellulases cost effectively.

\section{Methodology}

\section{Feedstock processing}

Parthenium hysterophorus biomass was used as a substrate for producing cellulases. It was procured from local areas, including road sides and the abandoned land. The biomass was washed thoroughly with tap water followed with its chopping and then oven drying at $50-60{ }^{\circ} \mathrm{C}$ for around $24 \mathrm{~h}$ (until complete drying). It was finally ground to a particle size of $0.5 \mathrm{~mm}$.

\section{Determination of biomass composition}

For cellulose content determination, $1 \mathrm{gm}$ of dried biomass was fluxed with $10 \mathrm{ml}$ of $80 \%$ acetic acid and $1.5 \mathrm{ml}$ of $\mathrm{HNO}_{3}$ for $20 \mathrm{~min}$ (Ahmed et al. 2010). The mixture was oven dried at $105{ }^{\circ} \mathrm{C}$ until constant weight and cellulose content $(\%)$ were calculated from the difference in the initial and final weights. Hemicellulose content was determined by the method by Blasi et al. (1999). For lignin content determination, modified method of TAPPI T 222 om-02 was used, in which biomass was hydrolysed with $72 \% \mathrm{H}_{2} \mathrm{SO}_{4}$ at $20{ }^{\circ} \mathrm{C}$ for $2 \mathrm{~h}$ followed with a filtration of contents. The solid residue was dried in an oven at $105^{\circ} \mathrm{C}$ until constant weight and lignin content (\%) were calculated from the difference in weight before and after acid hydrolysis.

\section{Microbial culture}

The microbial culture selected for the production of cellulases was Trichoderma reesei (NCIM 992), which was obtained from NCIM, Pune, India. It was maintained on potato dextrose agar (PDA) medium and preserved at $4{ }^{\circ} \mathrm{C}$. The purity of the culture was tested by observing the growth of the culture on agar medium as individual colony followed with its microscopic examination.

\section{Inoculum preparation}

For inoculum preparation, the culture was grown for 5 days in potato dextrose agar plates, at $30{ }^{\circ} \mathrm{C}$. For enzyme production, $10 \mathrm{~mm}$ disc of fungal mycelium $\left(\approx 2 \times 10^{7}\right.$ spores $/ \mathrm{ml}$ ) was inoculated per gram of cellulosic biomass.

\section{Solid-state fermentation}

For solid-state fermentation, the dried and ground biomass was taken in the Erlenmeyer flasks and solid-to-liquid ratio was maintained 1:2.5 using Mandel's medium ( $\mathrm{pH}$ 6.0) as a moistening agent. The Mandel's medium was prepared with the following composition $\left(\mathrm{gL}^{-1}\right)$ urea, 0.3 ; peptone, 0.1; $\left(\mathrm{NH}_{4}\right)_{2} \mathrm{SO}_{4}, 1.4 ; \mathrm{KH}_{2} \mathrm{PO}_{4}, 2.0 ; \mathrm{CaCl}_{2} \cdot 2 \mathrm{H}_{2} \mathrm{O}, 0.3$; $\mathrm{MgSO}_{4} \cdot 7 \mathrm{H}_{2} \mathrm{O}, 0.3$ and trace elements $\left(\mathrm{mgL}^{-1}\right): \mathrm{FeSO}_{4}$ $7 \mathrm{H}_{2} \mathrm{O}, 5 ; \mathrm{MnSO}_{4} \cdot \mathrm{H}_{2} \mathrm{O}, 1.6 ; \mathrm{ZnCl}_{2} \cdot 7 \mathrm{H}_{2} \mathrm{O}, 1.4$, and $\mathrm{CoCl}_{2}$ $6 \mathrm{H}_{2} \mathrm{O}, 2.0$. The contents of the flasks were sterilized in an autoclave at $121{ }^{\circ} \mathrm{C}$ at $15 \mathrm{psi}$ for $30 \mathrm{~min}$. The flasks were inoculated with fresh mycelium followed with their incubation at $30{ }^{\circ} \mathrm{C}$. All the experiments were performed in 
triplicates, and the data were expressed as mean \pm SD of three replicate samples. In addition, the analysis of variance was performed statistically using spss 16 according to Tukey's test at $5 \%$ probability $(p \leq 0.05)$.

\section{Enzyme extraction}

The enzyme was extracted using tenfolds (v/w) of sterilized distilled water. The contents were mixed thoroughly followed with the separation of liquid from the solid portion using a muslin cloth and then subjected to the centrifugation at $4{ }^{\circ} \mathrm{C}$ at $10,000 \mathrm{rpm}$ for $20 \mathrm{~min}$. The crude enzyme was finally obtained by filtering the supernatant through Whatman filter paper no. 1.

\section{Enzyme assays}

Endoglucanase activity (measured as Carboxymethyl cellulase, CMCase) and FPase activity (or total cellulase activity) were assayed according to the methods by Ghose (1987). The reaction mixture for CMCase activity consisted of $0.5 \mathrm{ml}$ of $1 \%(\mathrm{w} / \mathrm{v})$ carboxymethyl cellulose (prepared in $100 \mathrm{mM}$ sodium acetate buffer, $\mathrm{pH}$ 5.0) and $0.5 \mathrm{ml}$ of crude enzyme (appropriately diluted). For determining FPase activity, the reaction mixture consisted of $50 \mathrm{mg}$ of dry Whatman No. 1 filter paper strips $(6 \times 1 \mathrm{~cm})$ in $0.5 \mathrm{ml}$ of $100 \mathrm{mM}$ sodium acetate buffer $(\mathrm{pH} 5.0)$ with $0.5 \mathrm{ml}$ of appropriately diluted crude enzyme. The incubation was done at $50{ }^{\circ} \mathrm{C}$ for 10 and 60 min for CMCase and FPase assays, respectively. The reducing sugars liberated in the reaction were measured by dinitrosalicylic acid (DNS) method (Miller 1959) by adding $3 \mathrm{ml}$ of the DNS reagent to each reaction mixture followed with the boiling of the contents at $100{ }^{\circ} \mathrm{C}$ for 10-15 min for the color development. The absorbance was taken at $540 \mathrm{~nm}$. The amount of the glucose liberated was determined using the standard curve for glucose. One unit (IU) of enzyme activity is defined as the amount of enzyme required for producing $1 \mu \mathrm{mol}$ of reducing sugar (glucose) in the reaction mixture per minute under standard assay conditions. The enzyme activity was expressed as units per gram dry substrate (U/gds).

\section{Optimization of fermentation conditions for maximum cellulase production}

Optimization of cultural conditions (Table 1) was done using 'one variable at a time' approach to maximize the production of cellulase by $T$. reesei using Parthenium hysterophorus biomass.

\section{Incubation period}

To study the effect of the incubation period, $T$. reese $i$ was cultivated under solid-state conditions in different flasks and one flask at a time was taken out after incubation for 4 , $6,8,10,12$, and 14 days. The crude enzyme was extracted and used for enzyme assays.

\section{Initial moisture level}

During the solid-state fermentation conditions, the initial moisture level in different flasks was varied by keeping solid-to-liquid ratios $1: 1.25,1: 1.5,1: 1.75,1: 2,1: 2.25$, and $1: 2.5$. The incubation was done for time period optimized in above experiment.

\section{Temperature}

The effect of temperature was studied by producing cellulase from $T$. reese $i$ at different temperature conditions, i.e., $20,25,30,35$, and $40{ }^{\circ} \mathrm{C}$.

\section{Inoculum concentration}

The amount of the inoculum was optimized by inoculating the fermentation flasks with the different number of discs, i.e., 1-5, of $T$. reesei grown on potato dextrose agar medium.

\section{Inoculum age}

The effect of inoculum age, i.e., 48, 72, 96, 120, 144, 168, and $192 \mathrm{~h}$ old culture, was studied.

\section{Effect of carbon source and its concentration}

To study the effect of carbon sources, Mandel's medium was supplemented with $1 \%$ of different carbon sources, i.e., glucose, fructose, galactose, lactose, sucrose, cellobiose, starch, CMC, mannitol, and sorbitol. The effect of concentration of optimal carbon source was determined by varying its concentration from 0.25 to $2.5 \%$ at an interval of $0.25 \%$.

\section{Effect of nitrogen source and its concentration}

$1 \%$ of different nitrogen sources (inorganic and organic), i.e., urea, ammonium chloride, ammonium nitrate, ammonium sulphate, ammonium molybdate, $\mathrm{NaNO}_{3}, \mathrm{KNO}_{3}$, casein, peptone, beef extract, yeast extract, malt extract, and meat extract were incorporated in Mandel's medium, replacing other nitrogen sources. The effect of 


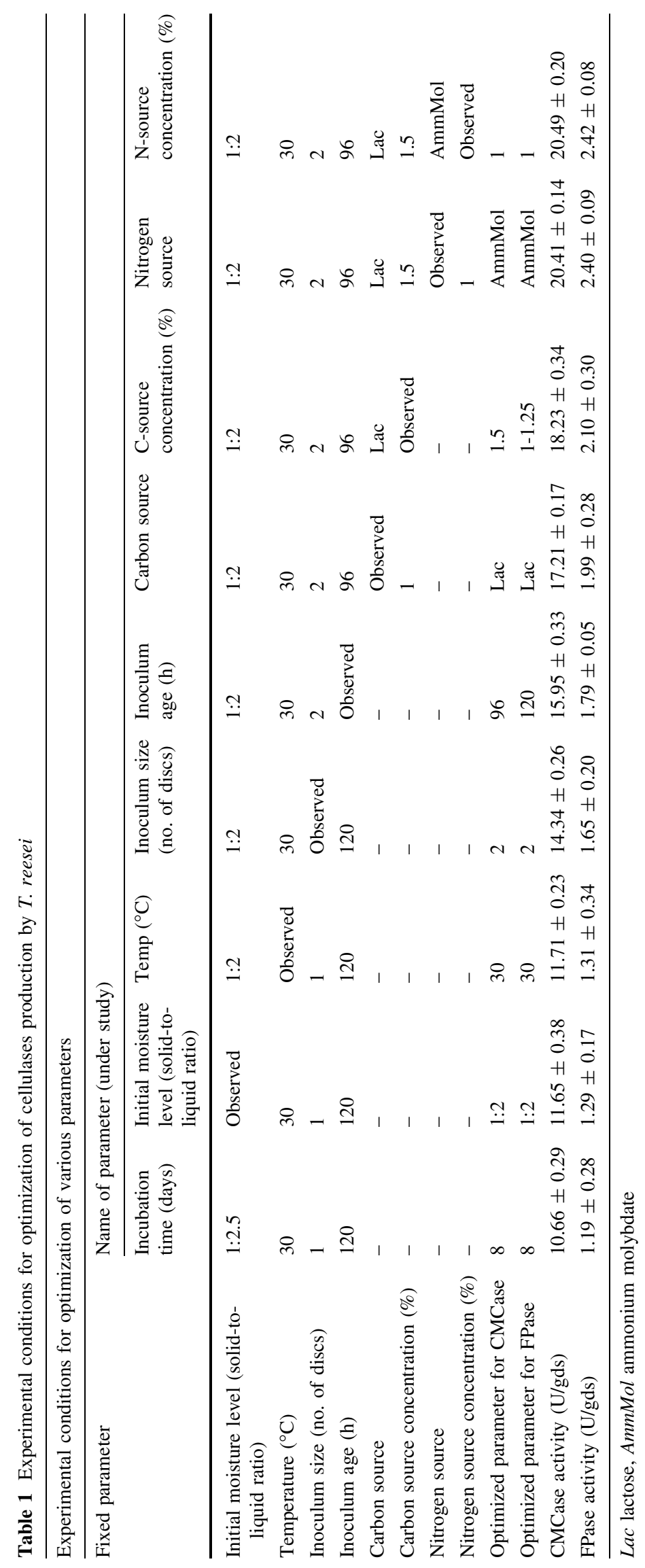


concentration of optimal nitrogen source was determined by varying its concentration from 0.25 to $2.0 \%$ at an interval of $0.25 \%$.

\section{Results and discussion}

\section{Biomass composition}

The untreated Parthenium biomass was found to have $36.11 \%$ cellulose content, $22.8 \%$ lignin, and $26 \%$ hemicellulose. Other studies have also revealed the presence of $28 \%$ (Shubhaneel et al. 2013) to $45 \%$ cellulose, $23 \%$ lignin, and $27 \%$ pentosans in the Parthenium biomass (Singh et al. 2014). These findings suggest that Parthenium can act as an effective carbon source for cellulase production by microbes.

\section{Incubation period}

The incubation period plays a very important role in the substrate utilization, growth rate of microorganism, and the enzyme synthesis. Hence, enzyme production was evaluated at different time periods from 4 (to allow sufficient fungal growth) to 14 days at intervals of 2 days (Table 2). From the results, it is clear that both CMCase and FPase values increased up to 8 days and activities were statistically different on the 4th and 8th days of incubation. A significant decline was observed upon further incubation. The maximum level of CMCase obtained on the 8th day was $10.66 \mathrm{U} / \mathrm{gds}$, while that of the FPase was $1.19 \mathrm{U} / \mathrm{gds}$. The decline in the activity after optimum incubation time could be attributed to several reasons, such as changes in the enzyme secretion machinery of the fungus under stressed conditions as a result of exhaustion of essential nutrients (Mrudula and Murugammal 2011), inhibitory effect of the cellobiose (Azzaz et al. 2012) or glucose accumulated in the medium, and protease production (Nathan et al. 2014) or other physiological conditions

Table 2 Effect of incubation period on cellulase production by $T$. reesei

\begin{tabular}{lll}
\hline Enzyme activity & \\
\hline Incubation time (days) & CMCase (U/gds) & FPase (U/gds) \\
\hline 4 & $06.54 \pm 0.33^{\mathrm{b}}$ & $0.84 \pm 0.16^{\mathrm{ab}}$ \\
6 & $07.74 \pm 0.25^{\mathrm{c}}$ & $1.10 \pm 0.27^{\mathrm{b}}$ \\
8 & $10.66 \pm 0.29^{\mathrm{d}}$ & $1.19 \pm 0.28^{\mathrm{b}}$ \\
10 & $07.30 \pm 0.38^{\mathrm{bc}}$ & $0.77 \pm 0.15^{\mathrm{ab}}$ \\
12 & $06.99 \pm 0.27^{\mathrm{bc}}$ & $0.68 \pm 0.12^{\mathrm{ab}}$ \\
14 & $04.64 \pm 0.32^{\mathrm{a}}$ & $0.52 \pm 0.10^{\mathrm{a}}$ \\
\hline
\end{tabular}

Values are mean \pm standard deviation. Data with the same superscript letter were not significantly different $(p<0.05$; Tukey test) unfavourable for enzyme stability. Studies have indicated variations in the optimal incubation period for the highest cellulase production depending on the microbial strains, fermentation conditions, and the type of substrate used. $T$. reesei produced maximum CMCase on the 6th day of incubation under SSF conditions using wheat bran as a substrate (Maurya et al. 2012), while T. reesie (Qm 9414 mutant) showed maximum production upon incubation for 10 days when water hyacinth was used as substrate for SSF (Deshpande et al. 2008).

\section{Initial moisture level}

The appropriate moisture of lignocellulosic substrate is one of the critical factors influencing productivity in solid-state fermentations (Liu and Yang 2007; Singhania et al. 2009). SSF requires the presence of moisture on the surface of biomass particles to support the growth of microorganisms, which in turn governs the production of enzymes (Raimbault 1998). Optimization of water level is essential as higher water content may result in bacterial contamination (Mienda et al. 2011), lower rate of oxygen transfer, and low nutrient solubility (Mrudula and Murugammal 2011), and causes substrate compaction and greater enzyme diffusion away from the substrate. On the other hand, the lower water content may reduce the nutrient diffusion, microbial growth, and enzyme stability (Gervais and Molin 2003). Therefore, an intermediate moisture content is required for efficient SSF (Laukevics et al. 1984), which is optimized under specific growth conditions for a microbial culture as well as the substrate because of variation in the water holding capacity of different biomass. Water also has implications for the physicochemical properties of the solid substrate, such as its swelling (Mrudula and Murugammal 2011). In the present study, T. reesei showed maximum activities for both CMCase (11.65 U/gds) as well as FPase (1.29 U/gds) when solid-to-liquid ratio was 1:2 (Table 3). A significant decline in CMCase value was recorded when the ratio was increased beyond 1:2. However, values of FPase were not statistically different when solid-to-liquid ratio was used over the range of 1:2-1:2.5. Singhania et al. (2006) have also reported 66\% initial moisture content optimal for maximum cellulase production by $T$. reesei NRRL 11460 during SSF with pretreated sugarcane bagasse. Maurya et al. (2012) found $70 \%$ initial moisture content optimal for the highest cellulase synthesis by $T$. reesei cultivated on wheat bran.

\section{Temperature}

The temperature optima for cellulase production can vary with the microbial strain (Murao et al. 1988), and the effect of incubation temperature on cellulase production is 
Table 3 Effect of initial moisture level on cellulase production by $T$. reesei

\begin{tabular}{lll}
\hline $\begin{array}{l}\text { Initial moisture level } \\
\text { (solid-to-liquid ratio) }\end{array}$ & $\begin{array}{l}\text { Enzyme activity } \\
\text { CMCase (U/gds) }\end{array}$ & FPase (U/gds) \\
\hline $1: 1.25$ & $01.41 \pm 0.15^{\mathrm{a}}$ & $0.16 \pm 0.05^{\mathrm{a}}$ \\
$1: 1.50$ & $06.82 \pm 0.55^{\mathrm{b}}$ & $0.45 \pm 0.09^{\mathrm{b}}$ \\
$1: 1.75$ & $07.87 \pm 0.23^{\mathrm{c}}$ & $0.99 \pm 0.12^{\mathrm{c}}$ \\
$1: 2.00$ & $11.65 \pm 0.38^{\mathrm{e}}$ & $1.29 \pm 0.17^{\mathrm{d}}$ \\
$1: 2.25$ & $10.71 \pm 0.41^{\mathrm{d}}$ & $1.24 \pm 0.13^{\mathrm{d}}$ \\
$1: 2.50$ & $10.60 \pm 0.31^{\mathrm{d}}$ & $1.21 \pm 0.14^{\mathrm{d}}$ \\
\hline
\end{tabular}

Values are means \pm standard deviations. Data with the same superscript letter were not significantly different $(p<0.05$; Tukey test)

primarily microbe dependent (Singhania et al. 2007; Yoon et al. 2014). The optimum temperature for microbial growth and cellulase production may vary; therefore, a balance is maintained during enzyme production (Yoon et al. 2014). The results of the effect of temperature on cellulase production by $T$. reesei grown on Parthenium biomass have been shown in Fig. 1. Maximum production was achieved at $30^{\circ} \mathrm{C}$, resulting in $11.71 \mathrm{U} / g d s$ CMCase and $1.31 \mathrm{U} / g d s$ FPase activities. Mukhopadhyaya and Nandi (1999) found $31{ }^{\circ} \mathrm{C}$ temperature optimum for cellulase production by $T$. reesei ATCC 26921 under shaking conditions using water hyacinth. The optimal temperature for cellulase production in T. reesei NRRL 11460 grown on pretreated sugarcane bagasse (Singhania et al. 2006) and $T$. reesei RUT C30 grown on wheat bran (Singhania et al. 2007) was 28 and $30^{\circ} \mathrm{C}$, respectively.

An increase or decrease in temperature from the optimum resulted in significant reduction in cellulase production by the fungal culture. High temperature showed a negative effect on the growth of T. reesei. Poor growth of the microorganism can be correlated with the reduced enzyme synthesis (Sethi and Gupta 2014). In SSF technique, $25-35^{\circ} \mathrm{C}$ is generally the preferable range of temperature (Mrudula and Murugammal 2011). A higher temperature is expected to denature enzymes due to heating effects (Yoon et al. 2014).

\section{Amount of inoculum}

The size of inoculum shows a significant effect on the enzyme production in both submerged and solid-state fermentation conditions. The CMCase $(14.34 \mathrm{U} / \mathrm{gds})$ and FPase (1.65 U/gds) activities were highest when two discs were used for inoculating per gram of the substrate (Table 4). During CMCase production from Aspergillus niger, ten discs of $8 \mathrm{~mm}$ diameter per $100 \mathrm{ml}$ of fermentation medium resulted in maximum enzyme synthesis in shaking conditions (Acharya et al. 2008). In another study, Aspergillus niger produced maximum cellulases when $15 \%$ $(\mathrm{v} / \mathrm{v})$ inoculum was used in solid-state conditions using coir waste as a substrate (Mrudula and Murugammal 2011). Trichoderma reesei cultivated on pineapple waste gave the highest activity when $6.6 \times 10^{8} \mathrm{CFU} / \mathrm{ml}$ of the inoculum was used (Saravanan et al. 2012).

An increase in the concentration resulted in a decrease in FPase activity. The activity decline with increased inoculum level can occur due to an imbalance between increasing biomass and nutrient's accessibility (Saravanan et al. 2012; El-Hadi et al. 2014) as well as interference in oxygen uptake and enzyme release due to clumping of cells (Dutt and Kumar 2014). On the other hand, low inoculum levels produce less biomass, leaving many nutrients unutilized, leading to reduced enzyme synthesis (El-Hadi et al. 2014).

\section{Inoculum age}

Age of the inoculum, a factor representing the physiological state of the fungus, affects biomass production
Fig. 1 Effect of temperature on cellulase production by $T$. reesei using Parthenium biomass. Data with the same letter were not significantly different $(p<0.05$; Tukey test $)$

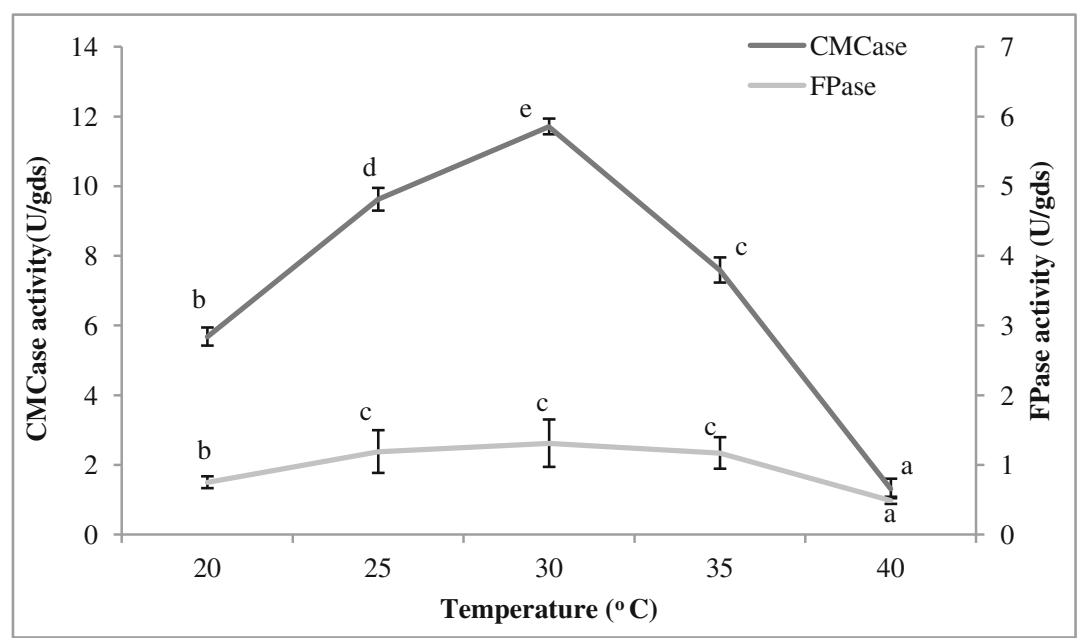


Table 4 Effect of inoculum level on cellulase production by T. reesei

\begin{tabular}{lll}
\hline $\begin{array}{l}\text { Inoculum level (no. of } \\
\text { discs/gm biomass) }\end{array}$ & \multicolumn{2}{l}{ Enzyme activity } \\
\cline { 2 - 3 } & CMCase (U/gds) & FPase (U/gds) \\
\hline 1 & $11.69 \pm 0.34^{\mathrm{a}}$ & $1.28 \pm 0.17^{\mathrm{b}}$ \\
2 & $14.34 \pm 0.25^{\mathrm{d}}$ & $1.65 \pm 0.20^{\mathrm{c}}$ \\
3 & $12.55 \pm 0.32^{\mathrm{bc}}$ & $1.39 \pm 0.12^{\mathrm{bc}}$ \\
4 & $12.79 \pm 0.18^{\mathrm{c}}$ & $1.22 \pm 0.11^{\mathrm{ab}}$ \\
5 & $12.26 \pm 0.43^{\mathrm{b}}$ & $0.95 \pm 0.14^{\mathrm{a}}$ \\
\hline
\end{tabular}

Values are means \pm standard deviations. Data with the same superscript letter were not significantly different ( $p<0.05$; Tukey test)

(Bhargav et al. 2008), which in turn can be responsible for enhanced synthesis of cellulases enzymes. CMCase and FPase production by Trichoderma reesei on Parthenium biomass was found maximum when $96 \mathrm{~h}(15.95 \mathrm{U} / \mathrm{gds}$ CMCase) and $120 \mathrm{~h}$ (1.79 U/gds FPase) old fungal culture was used as inoculum, respectively (Table 5). $\mathrm{Vu}$ et al. (2011) have found $48 \mathrm{~h}$ (2 days) old culture effective in maximum cellulase production by Aspergillus sp. SU14M15 under SSF conditions using wheat bran. Aspergillus hortai produced maximum levels of cellulase when $144 \mathrm{~h}$

Table 5 Effect of inoculum age on cellulase production by T. reesei

\begin{tabular}{lll}
\hline Time $(\mathrm{h})$ & \multicolumn{2}{l}{ Enzyme activity } \\
\cline { 2 - 3 } & CMCase $(\mathrm{U} / \mathrm{gds})$ & FPase $(\mathrm{U} / \mathrm{gds})$ \\
\hline 48 & $06.81 \pm 0.49^{\mathrm{a}}$ & $0.92 \pm 0.080^{\mathrm{a}}$ \\
72 & $15.29 \pm 0.33^{\mathrm{e}}$ & $1.33 \pm 0.075^{\mathrm{b}}$ \\
96 & $15.95 \pm 0.42^{\mathrm{e}}$ & $1.42 \pm 0.040^{\mathrm{bc}}$ \\
120 & $14.23 \pm 0.32^{\mathrm{d}}$ & $1.79 \pm 0.091^{\mathrm{de}}$ \\
144 & $13.53 \pm 0.44^{\mathrm{cd}}$ & $1.74 \pm 0.045^{\mathrm{e}}$ \\
168 & $12.88 \pm 0.19^{\mathrm{bc}}$ & $1.55 \pm 0.056^{\mathrm{cd}}$ \\
192 & $12.54 \pm 0.30^{\mathrm{b}}$ & $1.46 \pm 0.077^{\mathrm{bc}}$ \\
\hline
\end{tabular}

Values are means \pm standard deviations. Data with the same superscript letter were not significantly different ( $p<0.05$; Tukey test) old inoculum was used for liquid state fermentation (ElHadi et al. 2014). The effect of inoculum age on cellulase production can also be attributed to the fact that inoculum age and size affect fungal morphology (Ferreira et al. 2009) and optimal fungal morphology has been known to be correlated with enzyme production (Cui et al. 1998). Earlier studies have also indicated variation in the synthesis of different enzymes of the cellulase complex with the age of the culture (Umezurike 1975; Kahil and Hassan 2015). The difference in the optimal age for CMCase and FPase could be due to attainment of required biomass characteristics in $120 \mathrm{~h}$ for the synthesis of all components of the cellulase enzyme complex (measured as FPase) than $96 \mathrm{~h}$ required for only endoglucanase or CMCase. Morphological variations in microbial strains as a consequence of different parameters, including inoculum age, therefore, have marked influence on cellulase production (Ferreira et al. 2009).

\section{Carbon source and its concentration}

Cellulose in the Parthenium biomass supports the growth of $T$. reese $i$ as well as the cellulase production. However, the rate of the cellulases synthesis is generally slow when insoluble sugars in the lignocellulosic biomass are used as a substrate (Chen and Wayman 1992). Cellulases are inducible enzymes, and their production can be enhanced in the presence of other carbon sources (Jun et al. 2011). Therefore, the effect of various carbon sources was studied. Among different carbon sources tested (Fig. 2), lactose showed maximum enhancement in CMCase (17.21 U/gds) and FPase (1.99 U/gds) activities. Lactose is very widely used soluble carbon source for cellulase production (Wayman and Chen 1992). Studies have reported lactose among good inducers for cellulase production in T. reesei (Dashtban et al. 2011; Amore et al. 2013). Fang et al.
Fig. 2 Effect of different carbon sources on cellulase production by $T$. reesei using Parthenium biomass. Data with the same letter were not significantly different $(p<0.05$; Tukey test $)$

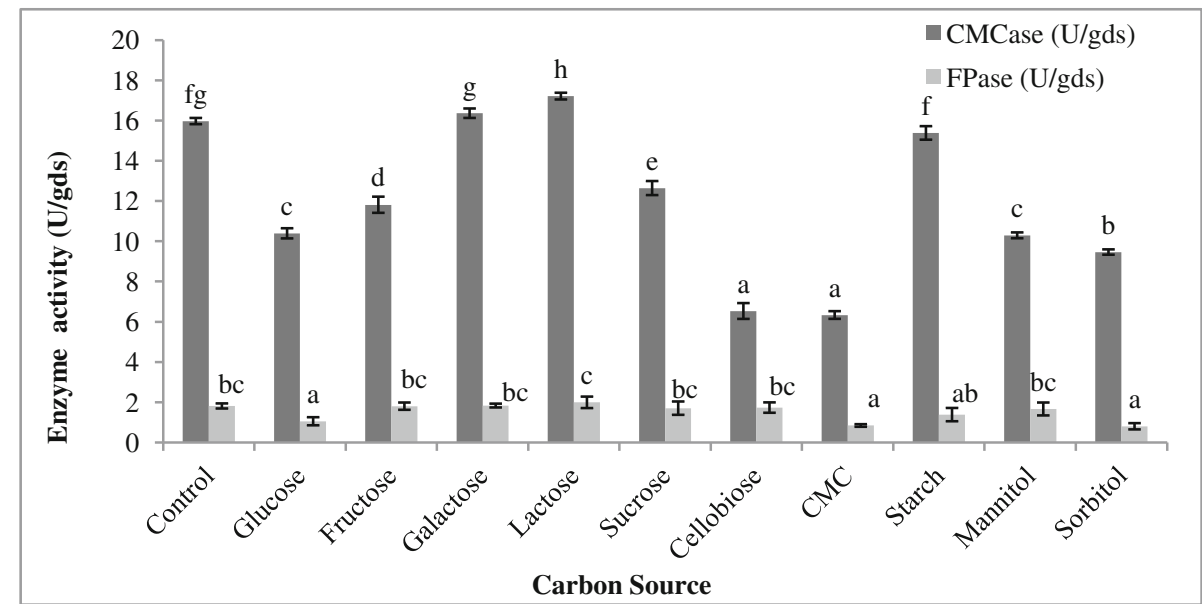

Carbon Source 
(2008) have shown the enhancing effect of the lactose on cellulase production by Acremonium cellulolyticus. In a study by Sun et al. (2010), Trihoderma species cultivated on apple pomace under SSF conditions produced the highest levels of cellulase when supplemented with lactose. In Acrophialophora nainiana also, the highest CMCase production was induced in the presence of lactose (Barros et al. 2010). Similarly, in Apsegillus hortai, enhanced CMCase production was observed in the presence of lactose (El-Hadi et al. 2014).

In studying the effect of carbon source concentration (Fig. 3), 1.5\% lactose concentration was found as optimum for the maximum production of CMCase (18.23 U/gds). The CMCase values were statistically not significantly different over the range from 0.75 to $1.25 \%$. Lower concentration, below $0.75 \%$, was unable to induce very high levels of CMCase suggesting that an appropriate concentration is desirable for induction of the enzyme systems. FPase activity was highest $(2.1 \mathrm{U} / \mathrm{gds})$ when lactose concentration was 1 or $1.25 \%$ (FPase values statistically similar).

\section{Nitrogen source and its concentration}

Choice of an appropriate nitrogen source for the cultivation of cellulolytic microbes is an important factor determining the yield of the process. Like carbon sources, the nitrogen sources have an inducible effect on the cellulases. The effect of different nitrogen sources on cellulase production by $T$. reesei, grown on Parthenium biomass, has been shown in Fig. 4. Ammonium molybdate nitrogen source caused maximum CMCase (20.41 U/gds) production compared to the control (18.19 U/gds), though production was significantly higher in the presence of peptone and yeast extract too. On the other hand, FPase activity increased to $2.40 \mathrm{U} / \mathrm{gds}$ with ammonium molybdate against $2.12 \mathrm{U} / \mathrm{gds}$ in control. Ammonium salts have been found as excellent nitrogen source for cellulase production by Trichoderma (Mukhopadhyaya and Nandi 1999) and other fungi, such as Apsergillus fumigatus (Stewart and Parry 1981) and Aspergillus terreus (Vyas et al. 2005). Different studies have indicated the enhancing effect of different ammonium salts. Shankar and Isaiarasu (2011) have found
Fig. 3 Effect of carbon source concentration on cellulase production. Data with the same letter were not significantly different $(p<0.05$; Tukey test)

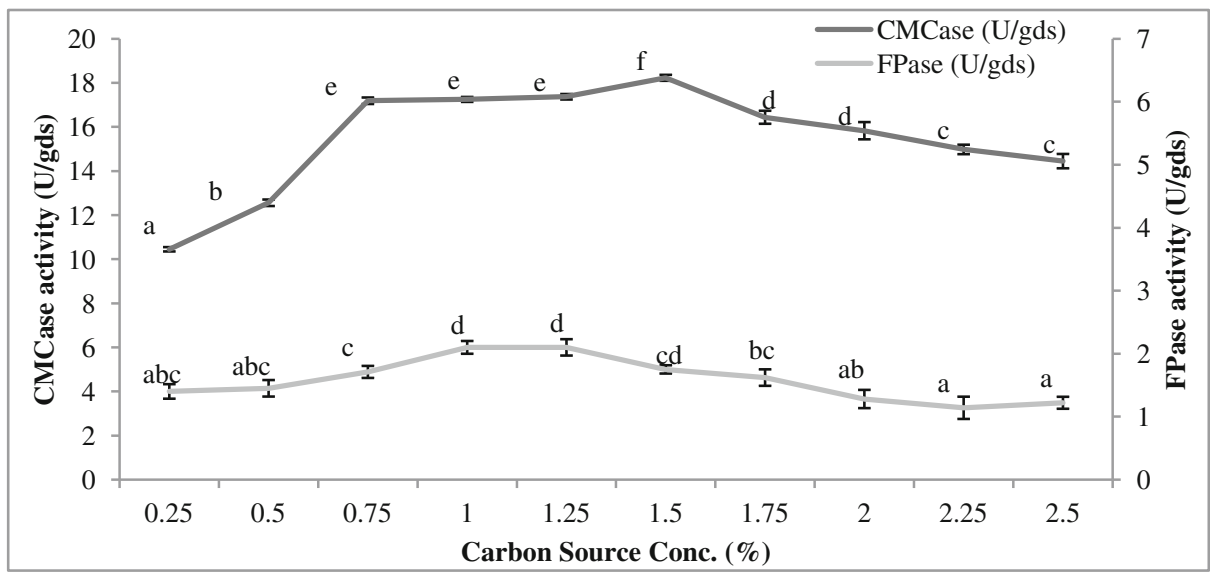

Fig. 4 Effect of different nitrogen sources on cellulase production by $T$. reesei using Parthenium biomass. Data with the same letter were not significantly different $(p<0.05$; Tukey test $)$

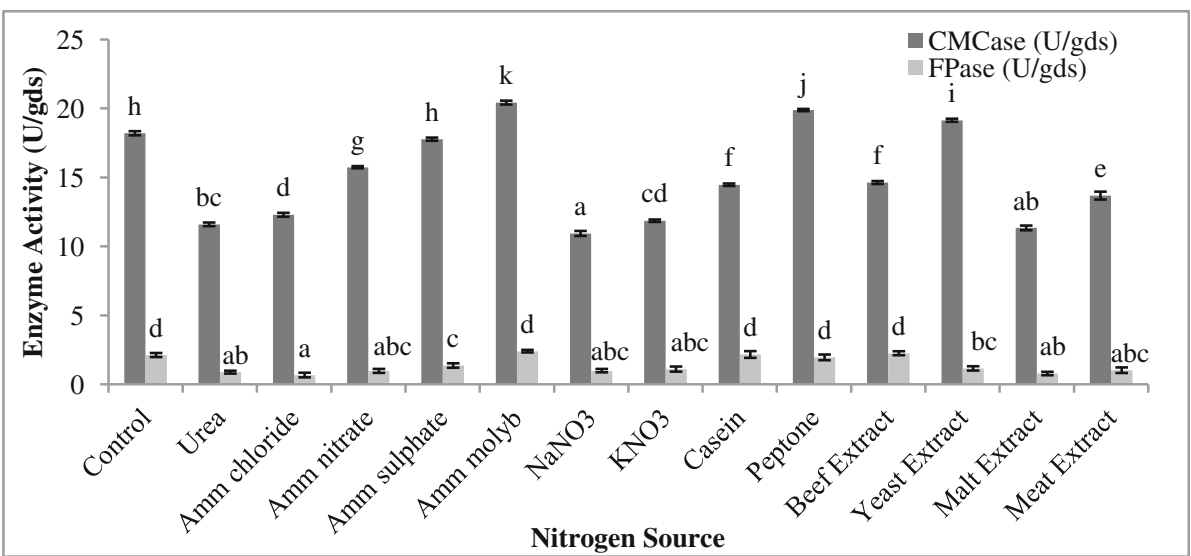


Fig. 5 Effect of nitrogen source concentration on cellulase production. Data with the same letter were not significantly different $(p<0.05$; Tukey test

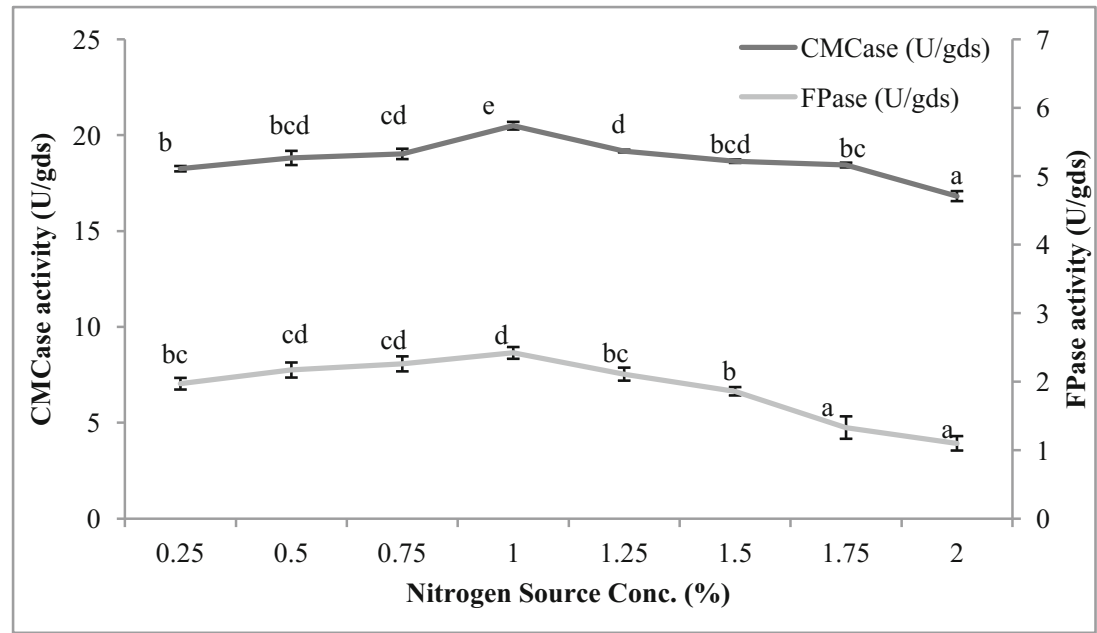

ammonium molybdate as the best nitrogen source for cellulase production by Bacillus pumilus EWBCM1. Inductive effect of ammonium salts can be attributed to the direct entry of ammonium in protein synthesis (Vyas et al. 2005). In the present study, $1 \%$ concentration of ammonium molybdate was found optimal for achieving maximum levels of CMCase (20.49 U/gds) and FPase (2.42 U/gds) (Fig. 5).

\section{Conclusion}

The present study indicates that Parthenium hysterophorus weed biomass can successfully be utilized for cellulase production. Optimization studies have demonstrated that significant enhancement in enzyme production is possible using suitable cultural conditions. Many of the discussed parameters showed marked effect on improvement in cellulase synthesis by $T$. reesei grown on the Parthenium biomass. Optimum conditions recorded were $30{ }^{\circ} \mathrm{C}$ incubation temperature, an incubation time of 8 days. and 1:2 initial solid-to-liquid ratio. Supplementation with $1.5 \%$ lactose and $1 \%$ ammonium molybdate further increased both CMCase and FPase activities. Appropriate inoculum age and inoculum level, i.e., $96-120 \mathrm{~h}$ and 2 discs per gram of biomass, respectively, were also found important factors affecting cellulase production.

The Parthenium biomass was not subjected to any physicochemical pretreatment. This was intended to minimize the cost of cellulase production from Parthenium biomass using it in untreated form, because pretreatment is known to increase the production cost many folds. Moreover, the current work included the preliminary study to first test the potency of weed biomass for cellulase production. However, this work can subsequently be extended to bioethanol production. In addition, management of Parthenium hysterophorus has been a concern for many years. A lot of research inputs and financial investments in this regard have been unsuccessful in controlling this weed in an eco-friendly manner. The utilization of Parthenium hysterophorus biomass for cellulase production does not only suggest the potential of this weed for various lignocellulose-based applications, but also the solution for controlling this noxious weed to manageable levels.

\section{Compliance with ethical standards}

Conflict of interest The authors declare that there is no conflict of interests.

Open Access This article is distributed under the terms of the Creative Commons Attribution 4.0 International License (http:// creativecommons.org/licenses/by/4.0/), which permits unrestricted use, distribution, and reproduction in any medium, provided you give appropriate credit to the original author(s) and the source, provide a link to the Creative Commons license, and indicate if changes were made.

\section{References}

Acharya PB, Acharya DK, Modi HA (2008) Optimization for cellulase production by Aspergillus niger using saw dust as substrate. Afr J Biotechnol 7:4147-4152

Ahmed I, Zia MA, Iqbal HMN (2010) Bioprocessing of proximally analyzed wheat straw for enhanced cellulase production through process optimization with Trichoderma viride under SSF. Int J Biol Life Sci 6:164170

Amore A, Giacobbe S, Faraco V (2013) Regulation of cellulase and hemicellulase gene expression in fungi. Curr Genomics 14:230-249. doi:10.2174/1389202911314040002

Azzaz HH, Murad HA, Kholif AM, Hanfy MA, Gawad MHA (2012) Optimization of culture conditions affecting fungal cellulase production. Res J Microbiol 7:23-31

Balat M, Balat H (2009) Recent trends in global production and utilization of bioethanol fuel. App Energ 86:2273-2282. doi:10. 1016/j.apenergy.2009.03.015

Barros RR, Oliveira RA, Gottschalk LM, Bon EP (2010) Production of cellulolytic enzymes by fungi Acrophialophora nainiana and Ceratocystis paradoxa using different carbon sources. Appl 
Biochem Biotechnol 161:448-454. doi:10.1007/s12010-0098894-3

Bhargav S, Panda BP, Ali M, Javed S (2008) Solid-state fermentation: an overview. Chem Biochem Eng Q 22:49-70. doi:10.1080/ 07388550590925383

Blasi CD, Signorelli G, Russo CD, Rea G (1999) Product distribution from pyrolysis of wood and agricultural residues. Ind Eng Chem Res 38:2216-2224. doi:10.1021/ie980711u

Brodeur G, Yau E, Badal K, Collier J, Ramachandran KB, Ramakrishnan S (2011) Chemical and physicochemical pretreatment of lignocellulosic biomass: a review. Enzyme Res 2011:1-17. doi: $10.4061 / 2011 / 787532$

Brown RM Jr. (1979) Biogenesis of natural polymer systems, with special reference to cellulose assembly and deposition. In: Proceedings of the Third Phillip Morris USA Operations Center. Richmond, Virginia, pp 50-123

Chen S, Wayman M (1992) Novel inducers derived from starch production by Trichoderma reesei. Process Biochem 27:327-334. doi:10.1016/0032-9592(92)87010-E

Cherry JR, Fidantsef AL (2003) Directed evolution of industrial enzymes: an update. Curr Opin Biotechnol 14:438-443. doi:10. 1016/S0958-1669(03)00099-5

Cui YQ, Ouwehand JNW, Van Der Lans RGJM, Giuseppin MLF, Luyben KCAM (1998) Aspects of use of complex media for submerged fermentation of Aspergillus awamori. Enzyme Microb Technol 23:168-177. doi:10.1016/S01410229(98)00038-6

Damaso MCT, Terzi SC, Farias AX, de Oliveira ACP, Fraga ME, Couri S (2012) Selection of cellulolytic fungi isolated from diverse substrates. Braz Arch Biol Technol 55:513-520. doi:10. 1590/S1516-89132012000400005

Dashtban M, Buchkowski R, Qin W (2011) Effect of different carbon sources on cellulase production by Hypocrea jecorina(Trichoderma reesei) strains. Int J Biochem Mol Biol 2:274-286

Deshpande SK, Bhotmange MG, Chakrabarti T, Shastri PN (2008) Production of cellulase and xylanase by Trichoderma reese $i$ (QM 9414 mutant), Aspergillus niger and mixed culture by solid state fermentation (SSF) of water hyacinth (Eichhornia crassipes). Indian J Chem Technol 15:449-456

Dutt D, Kumar A (2014) Optimization of cellulase production under solid state fermentation by Aspergillus flavus (AT-2) and Aspergillus niger (AT-3) and its impact on stickies and ink particle size of sorted office paper. Cellulose Chem Technol 48:285-298

El-Hadi AA, El-Nour SA, Hammad A, Kamel Z, Anwar M (2014) Optimization of cultural and nutritional conditions for carboxymethylcellulase production by Aspergillus hortai. J Radiat Res App Sci 7:23-28. doi:10.1016/j.jrras.2013.11.003

Fang X, Yano S, Inoue H, Sawayama S (2008) Lactose enhances cellulase production by the filamentous fungus Acremonium cellulolyticus. J Biosci Bioeng 106:115-120. doi:10.1263/jbb. 106.115

Ferreira SMP, Duarte AP, Queiroz JA, Domingues FC (2009) Influence of buffer systems on Trichoderma reesei Rut C-30 morphology and cellulase production. Electron $\mathrm{J}$ Biotechnol 12:1-9. doi:10.2225/vol12-issue3-fulltext-6

Gervais P, Molin P (2003) The role of water in solid-state fermentation. Biochem Eng J 13:85-101. doi:10.1016/S1369$703 X(02) 00122-5$

Ghose TK (1987) Measurements of cellulase activities. Pure Appl Chem 59:257-268

Isarankura-Na-Ayudhya $\mathrm{C}$, Tanawut $\mathrm{T}$, Hikamporn $\mathrm{K}$, Ponpitak $\mathrm{P}$, Virapong P (2007) Appropriate technology for the bioconversion of Water Hyacinth (Eichhornia crassipes) to liquid ethanol: future prospects for community strengthening and sustainable Development. EXCLI 6:167-176
Jun H, Kieselbach T, Jönsson LJ (2011) Enzyme production by filamentous fungi: analysis of the secretome of Trichoderma reesei grown on unconventional carbon source. Microb Cell Fact 10:1-10. doi:10.1186/1475-2859-10-68

Kahil T, Hassan HM (2015) Economic co-production of cellulase and $\alpha$-amylase by fungi grown on agro-industrial wastes using solidstate fermentation conditions. Middle East J Apppl Sci 5:184-195

Kirk O, Borchert TV, Fuglasang CC (2001) Industrial enzyme applications. Curr Opin Biotechnol 13:345-351. doi:10.1016/ S0958-1669(02)00328-2

Klein-Marcuschamer D, Oleskowicz-Popiel P, Simmons BA, Blanch HW (2012) The challenge of enzyme cost in the production of Lignocellulosic biofuels. Biotechnol Bioeng 109:1083-1087. doi: $10.1002 /$ bit. 24370

Klemm D, Heublein B, Fink HP, Bohn A (2005) Cellulose: fascinating Biopolymer and sustainable raw material. Angew Chem Int Ed 44:3358-3393. doi:10.1002/anie.200460587

Laukevics JJ, Aspite AF, Veistures VE, Tengerdy RP (1984) Solid state fermentation of wheat straw to fungal protein. Biotechnol Bioeng 26:1465-1474. doi:10.1002/bit.260261211

Limayem A, Ricke SC (2012) Lignocellulosic biomass for bioethanol production: current perspectives, potential issues and future prospects. Prog Energ Combust Sci 38:449-467

Liu J, Yang J (2007) Cellulase production by Trichoderma koningii AS3.4262 in solid-state fermentation using lignocellulosic waste from the vinegar Industry. Food Technol Biotechnol 45:420-425

Maurya DP, Singh D, Pratap D, Maurya JP (2012) Optimization of solid state fermentation conditions for the production of cellulase by Trichoderma reesei. J Env Biol 33:5-8

Mienda BS, Idi A, Umar A (2011) Microbiological features of solid state fermentation and its applications-an overview. Res Biotechnol 2:21-26

Miller GL (1959) Use of dinitrosalicylic acid reagent for determination of reducing sugar. Anal Chem 3:426-428. doi:10.1021/ ac60147a030

Mrudula S, Murugammal S (2011) Production of cellulase by Aspegillus niger under submerged and solid state fermentation using coir waste as a substrate. Braz J Microbiol 42:1119-1127

Mukhopadhyaya S, Nandi B (1999) Optimization of cellulase production by Trichoderma reesei ATCC 26921 using a simplified medium on water hyacinth biomass. J Sci Ind Res 58:107-111

Murao S, Sakamoto R, Arai M (1988) Cellulase of Aspergillus aculeatus. In: Wood WA, Kellog ST (eds) Methods in enzymology, vol 160. Academic Press, London, pp 275-284

Nathan VK, Rani ME, Rathinasamy G, Dhiraviam KN, Jayavel S (2014) Process optimization and production kinetics for cellulase production by Trichoderma viride VKF3. SpringerPlus 3:1-12

Patel S (2011) Harmful and beneficial aspects of Parthenium hysterophorus: an update. 3 Biotech 1:1-9. 10.1007/s13205011-0007-7

Raimbault M (1998) General and microbiological aspects of solid substrate fermentation. Electron J Biotechnol 3:1-9

Ruegger MJS, Tauk-tornisielo SM (2004) Cellulase activity of fungi isolated from soil of the Ecological Station of Juréia-Itatins, São Paulo, Brazil. Rev Brasil Bot 27:205-211. doi:10.1590/S010084042004000200001

Saravanan P, Muthuvelayudham R, Rajesh Kannan R, Viruthagiri T (2012) Optimization of cellulase production using Trichoderma reesei by RSM and comparison with genetic algorithm. Front Chem Sci Eng 6:443-452. doi:10.1007/s11705-012-1225-1

Sethi S, Gupta S (2014) Optimization of cultural parameters for cellulase enzyme production from fungi. BioLife 2:989-996

Shahzadi T, Mehmood S, Irshad M, Anwar Z, Afroz A, Zeeshan N, Rashid U, Sughra K (2014) Advances in lignocellulosic 
biotechnology: a brief review on lignocellulosic biomass and cellulases. Adv Biosci Biotechnol 5:246-251. doi:10.4236/abb. 2014.53031

Shankar T, Isaiarasu L (2011) Cellulase production by Bacillus pumilus EWBCM1 under varying cultural conditions. Middle East J Sci Res 8:40-45

Shubhaneel N, Ghosh S, Haldar S, Ganguly A, Chatterjee PK (2013) Acid catalyzed auto-hydrolysis of Parthenium Hysterophorus L. for Production of Xylose for Lignocellulosic Ethanol. Int J Emerg Technol Adv Eng 3:187-192

Singh A, Khanna S, Moholkar VS, Goyal A (2014) Screening and optimization of pretreatments for Parthenium hysterophorus as feedstock for alcoholic biofuels. Appl Energ 129:195-206

Singhania RR, Patel AK, Saccol CR, Pandey A (2009) Recent advance in solid state fermentation. Biochem Eng J 44:13-18

Singhania RR, Sukumaran RK, Pandey A (2007) Improved cellulase production by Trichoderma reesei RUT C30 under SSF through process optimization. Appl Biochem Biotechnol 142:60-70. doi:10.1007/s12010-007-0019-2

Singhania RR, Sukumaran RK, Pillai A, Verma P, Szakacs G, Pandey A (2006) Solid state fermentation of lignocellulosic substrates for cellulosic production by Trichoderma reesie NRRL 11460 . Indian J Biotechnol 5:332-336

Stewart JC, Parry JB (1981) Factors influencing the production of cellulase by Aspergillus fumigatus (Fresenius). J Gen Microbiol 125:33-39. doi:10.1099/00221287-125-1-33

Sukumaran RK, Singhania RR, Pandey A (2005) Microbial cellulases- production, applications and challenges. J Sci Ind Res 64:832-844
Sun H, Ge X, Hao Z, Peng M (2010) Cellulase production by Trichoderma sp. on apple pomace under solid state fermentation. Afr J Biotechnol 9:163-166. doi:10.4314/ajb.v9i2

TAPPI Test Method T222 om-06. Acid-insoluble lignin in wood and pulp. Technical Association of the Pulp and Paper Industry, Tappi Test Methods, Atlanta, GA

Umezurike GM (1975) Kinetic analysis of the mechanism of action of $\beta$-glucosidase from Botryodiplodia theobromae Pat. Biochim Biophys Acta 397:164. doi:10.1016/0005-2744(75)90190-4

Verma N, Bansal MC, Kumar V (2011) Pea peel waste: a lignocellulosic waste and its utility in cellulase production by Trichoderma reesei under solid state cultivation. Bioresoucr 6:1505-1519

$\mathrm{Vu}$ VH, Pham TA, Kim K (2011) Improvement of fungal cellulase production by mutation and optimization of solid state fermentation. Mycobiol 39:20-25. doi:10.4489/MYCO.2011.39.1.020

Vyas A, Vyas D, Vyas KM (2005) Production and optimization of cellulases on pretreated groundnut shell by Aspergillus terreus AV49. J Sci Ind Res 64:281-286

Wayman M, Chen S (1992) Cellulase production by Trichoderma reesei using whole wheat flour as a carbon source. Enzyme Microb Technol 14:825-831. doi:10.1016/0141-0229(92)90099A

Wilson DB (2011) Microbial diversity of cellulose hydrolysis. Curr Opin Microbiol 14:1-5. doi:10.1016/j.mib.2011.04.004

Yoon LW, Ang TN, Ngoh GC, Chua ASM (2014) Fungal solid-state fermentation and various methods of enhancement in cellulase production. Biomass Bioenerg 67:319-338. doi:10.1016/j. biombioe.2014.05.013 